\title{
River Flood Monitoring for Prediction of Hazards for Pipeline System
}

ISSN: 2576-8840

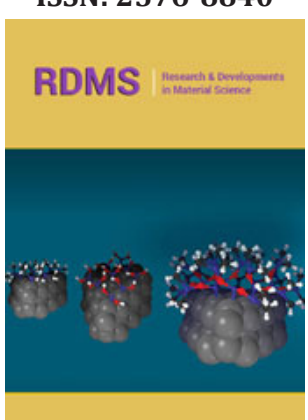

${ }^{* 1}$ Corresponding author: Rustam B Rustamov, SMEC, Australiaei Link R\&D Center, Azerbaijan

\section{Submission: 侮 March 23, 2019}

Published: 制April 01, 2019

Volume 10 - Issue 3

How to cite this article: Rustam B R, Bahar N A. River Flood Monitoring for Prediction of Hazards for Pipeline System. Res Dev Material Sci. 10(3).RDMS.000737.2019. DOI: 10.31031/RDMS.2019.10.000737

Copyright@ Rustam B Rustamov, This article is distributed under the terms of the Creative Commons Attribution 4.0 International License, which permits unrestricted use and redistribution provided that the original author and source are credited.

\section{Abstract}

Today advances in information systems, satellites imaging systems and improved software technologies have led to opportunities for a new level of information products from remote sensed data. The integration of these new products into existing response systems can provide a wide range of analysis tools and information products on the base of developed geographical information system (GIS). Using the higher resolution of space imagery and change detection analysis natural disaster awareness and damage assessment can be conducted rapidly and accurately. On the base of the developed database the use of the remote sensing methods and GIS technology provides resources and opportunities of prediction and reduction of natural risk due to the timely implementation of appropriate engineering and technological activities.

This paper describes results of study of island and channel forming processes on the Kura River and its crossing with linear system oil or gas pipeline. The aim of this study is to analyse the current condition of the pipeline and assess the potential threats to its integrity, identify the remediation measures for the Kura River crossing and ensure that the proposed methods allow to retain the integrity of the pipeline.

Keyword: Remote sensing and geographical information system; Linear system; Data processing; field measurement; Satellite image

\section{Introduction}

The Kura river is the largest river of Azerbaijan. It stretches for 1,515 kilometers and covers an area of 188 thousand sq. km. The Kura River originates from the Hel River in Turkey, passes through Georgia and Azerbaijan and flows into the Caspian Sea in South-Eastern part of the country.

There are number of oil and gas export pipelines in Absheron peninsula, Azerbaijan, which cross the Kura River downstream of the important road and railway bridges. The investigated area of pipeline crossing the river stream is located at the North-West of Azerbaijan. Prior to the pipeline construction at the investigated area an island was formed and continued growing in the center of the river, downstream of the bridges and near the river crossing. The formation and growth of the island has a significant impact on the channel morphology. It resulted with certain effects to the linear system integrity.

The bridge piers maintain the river channel stability preventing lateral movement in this area. However, downstream the river movement and the bridge openings allow the river some freedom of direction. In this paper the results of the studies performed for the Kura River crossing were analyzed and the recommendations provided for appropriate authorities for further decision-making stage.

\section{Methodology}

This study was carried out to identify the most critical impacts on the linear pipeline integrity caused by the Kura River. With this purpose the following data was studied and analyzed:

A. Information regarding flow rates, water consumption and turbidity;

B. Satellite images indicating island growth and the river channels transformation over time; 
C. Information regarding yearly change of the Kura River and island based on geodetic and topographical data;

D. Information regarding yearly change of the river channels width and depth based on the river sections; and

E. Field survey results provided by Company.

Based on the collected information from different sources, the annual changes of the river were studied, the most critical and sensitive points identified and the minimum measures that would provide a reliable solution to support the linear system integrity developed.

\section{Study and analysis}

Statistical data has been collected, reviewed, and topographical maps and sections compared to identify the yearly change in the Kura River sleeves and island between 2007 and 2016. The use and application of space technology is suitable in many cases, particularly for the case of river flow rate estimation due to the covering a large area, high accuracy, availability of application in the unacceptable areas etc. Moreover, according to the created and developed database there is an advantage to be very sensitive to any available change occurred in the investigated areas.

The benefits of analysis of natural risk reduction involves a number of particular challenges, including:

A. Little related information may be available on the frequency and intensity of the hazard event implying uncertainty about the level of risk.

B. Many of the benefits of any natural risk reduction measures, whether undertaken in the context of a disaster risk reduction project or as part of another type of development project, are related to the direct and indirect losses that will not ensue should the related hazard event occur constantly, rather than streams of positive benefits that will take place, as would be the case for other investments. This can present certain measurement difficulties.

\section{Problem description}

Subsequent to pipeline construction, an island of presumably alluvial origin had further formed in the center of the river, downstream of the bridges and near the river crossing. This island is seen on satellite image from 2001 (Figure 1, 2), however, the construction works of the railway bridge in 2013 could have an influence on the island growth as the river bed was not cleaned properly upon completion of the activities which was necessary to keep the river downstream in working condition. The alluvial island in the Kura River channel represents a plot of land of elliptic shape stretched in an east-west direction with an area of 101597.687 in 2016 (measurements are taken within boundaries of section \#4\#4a). The island is formed with coarse sand and gravel material. The landscape of the island is hilly, the maximum difference between the lowest (202.10) and highest (205.59) elevations is $3.5 \mathrm{~m}$ (according to topographical survey of 2013). The island is partly covered with vegetation.

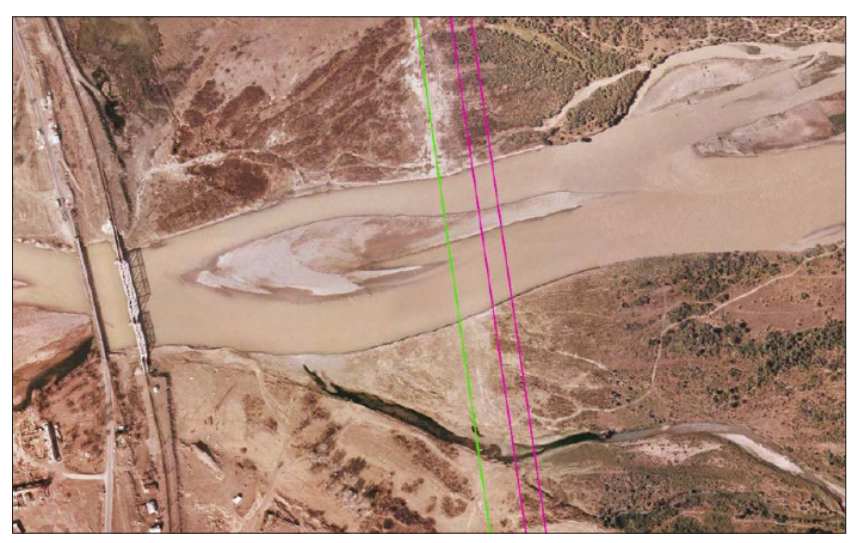

Figure 1: River plan at Kura West crossing 2001.

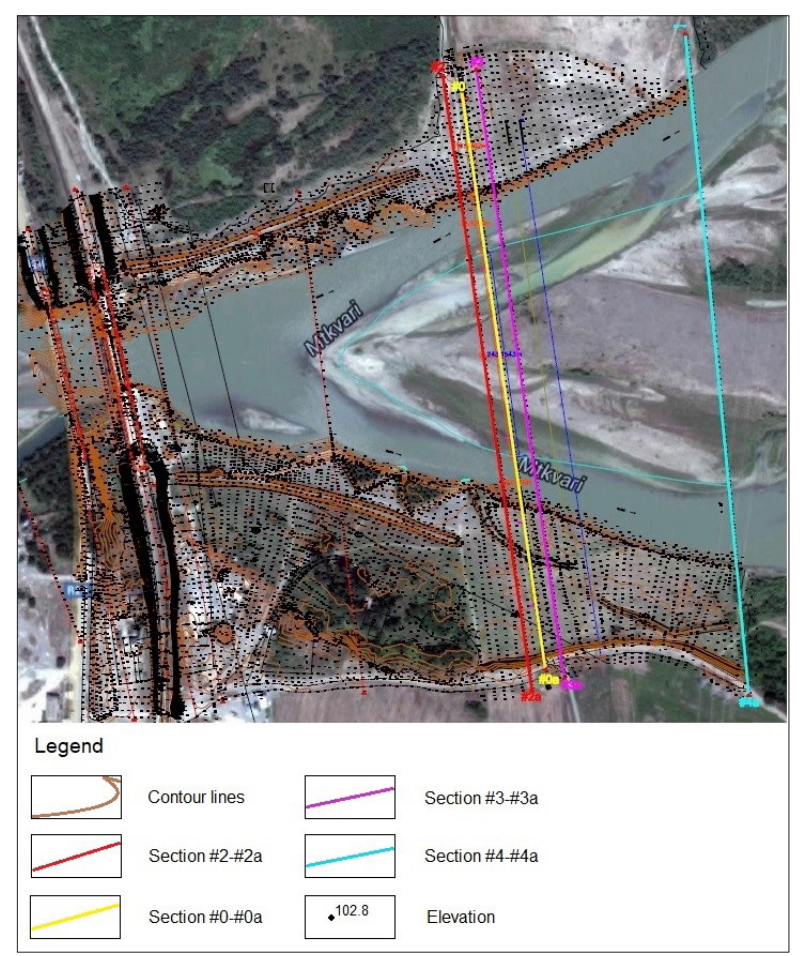

Figure 2: River plan at Kura West crossing 2016 (merged with topographical map of 2016).

There are two ways that the island could have formed in the Kura River channel:

A. A secondary channel could diverge from the main channel, encircling a portion of the floodplain before returning to the main river;

B. A blockage within the active channel could have resulted in sediment deposition and the emergence of the island.

The mechanism of the gravel bar formation is based on the interaction of zones of washout and sediments deposition at high flow levels. During base flow conditions, river basins are sites of flow-pathway divergence and therefore sediment deposition. Riffles are sites of flow convergence and therefore erosion. When flow levels approach bank full, the relationship reverses, and sediments are washed out from river basins and deposited on the 
crest of downstream riffles. As the river level falls, the top of such riffles may appear as a gravel bar.

A second method of gravel bar formation commences when a piece of large woody debris lodges in the river channel. The tree roots can serve as a barrier to flow, thus the flowing water must diverge around the obstruction. At the point where the stream diverges around the roots, the stream velocity decreases and sediment deposition can occur. The alluvial island formed in

Table 1: Yearly change of alluvial island area. the Kura River channel has grown larger during the past years. According to topographical maps provided by Company, the area of the island changed as is presented in Table 1 (area was calculated within boundary of section \#4-\#4a). As can be seen from Table 1, the area of the island significantly increased between 2008 and 2016 from $17521.518 \mathrm{~m}^{2}$ to $101597.687 \mathrm{~m}^{2}$. Although there was a single island, between 2010 and 2013 this land was divided by two and four small plots of land. However, in 2014 these plots formed a uniform island again.

\begin{tabular}{|c|c|c|}
\hline Year & $\begin{array}{c}\text { Island Area, } \\
\mathbf{m}^{2}\end{array}$ & \\
\hline 2007 & 38090.406 & \\
\hline 2008 & 17521.518 & \\
\hline 2009 & 87379.199 & \\
\hline 2010 & 90263.498 & Note \\
\hline 2011 & 92830.115 & Total island area consists of four plots of land with areas of $2641.358 ; 5560.793 \mathrm{~m}^{2} ; 7459.47 \mathrm{~m}^{2} ; 77168.491 \mathrm{~m}^{2}$ \\
\hline 2012 & 106496.485 & Total island area consists of four plots of land with areas of $2796.504 \mathrm{~m}^{2} ; 1527.368 \mathrm{~m}^{2} ; 9745.504 \mathrm{~m}^{2} ; 92427.109 \mathrm{~m}^{2}$ \\
\hline 2013 & 128515.714 & Total island area consists of two plots of land with areas of $3920.468 \mathrm{~m}^{2} ; 124595.273 \mathrm{~m}^{2}$ \\
\hline 2014 & 134796.334 & \\
\hline 2015 & 135469.375 & \\
\hline 2016 & 101597.687 & \\
\hline
\end{tabular}

\section{River history}

According to the information provided by the Ministry of Ecology and Natural Resources, the Kura-Giragkesemen hydrological station located in Giragkesemen village of Agstafa district has been used since 06.07.1985. The catchment basin of the Kura River is $35900 \mathrm{~km}^{2}$, flood periods are spring and autumn, shallow waters are observed in winter and summer. During the observation period the average water consumption during flood period was equal to $301 \mathrm{~m}^{3} / \mathrm{s}$, during shallow water this dropped to $137 \mathrm{~m}^{3} / \mathrm{s}$. Maximum water consumption in the river was registered on $28.04 .2005\left(2496 \mathrm{~m}^{3} / \mathrm{s}\right)$, minimum on $21.08 .2000\left(36 \mathrm{~m}^{3} / \mathrm{s}\right)$. Maximum water level was registered on $12.06 .1987(669 \mathrm{~cm})$, minimum on 24.08 .2010 (196cm).
During the observation period the average registered water velocity was equal to $1.21 \mathrm{~m} / \mathrm{s}$, and maximum velocity was $3.80 \mathrm{~m} / \mathrm{s}$. Maximum turbidity in the river water is $5500 \mathrm{~g} / \mathrm{m}^{3}$. Within the boundaries of the investigated area, the Kura River represents the main river channel divided by two sleeves (left and right) due to the presence of an alluvial island in the middle of the river. Information regarding yearly change in river behavior along the section \#0-0 is presented in Table 2 where width and depth of the river as well as distance of the river bank from the pipeline, was compared between 2009 and 2016. Table 3-5 represent the same information for sections \#2-\#2a, \#3-\#3a and \#4-\#4a. Information sources provide various values for the water consumption of the Kura River. In our calculations we used the average water consumption of $301 \mathrm{~m}^{3} / \mathrm{s}$, provided by the Ministry of Ecology and Natural Resources.

Table 2: Kura River yearly data 2009-2016 along section \#0-\#0a.

\begin{tabular}{|c|c|c|c|c|c|c|c|c|c|}
\hline \multirow[b]{2}{*}{ Year } & \multirow[b]{2}{*}{$\begin{array}{c}\text { Island } \\
\text { Width, m }\end{array}$} & \multicolumn{4}{|c|}{ Left Sleeve } & \multicolumn{4}{|c|}{ Right Sleeve } \\
\hline & & $\begin{array}{l}\text { Width of } \\
\text { left sleeve, } \\
\text { m }\end{array}$ & $\begin{array}{l}\text { Maximal depth } \\
\text { of left sleeve, m }\end{array}$ & $\begin{array}{c}\text { Cross section } \\
\text { of left sleeve, } \\
\text { m }^{2}\end{array}$ & $\begin{array}{l}\text { River flow } \\
\text { rate in left } \\
\text { sleeve, m/s }\end{array}$ & $\begin{array}{l}\text { Width } \\
\text { of right } \\
\text { sleeve, m }\end{array}$ & $\begin{array}{l}\text { Maximal } \\
\text { depth of right } \\
\text { sleeve, } \mathbf{m}\end{array}$ & $\begin{array}{l}\text { Cross sec- } \\
\text { tion of right } \\
\text { sleeve, } \mathbf{m}^{2}\end{array}$ & $\begin{array}{l}\text { River flow } \\
\text { rate in right } \\
\text { sleeve, m/s }\end{array}$ \\
\hline 2009 & 169.7 & 87.33 & 2.35 & 84.64 & 2.94 & 113.71 & 0.93 & 67.42 & 2.88 \\
\hline 2010 & 149.3 & 91.00 & 1.00 & 85.46 & 2.61 & 96.00 & 1.00 & 70.24 & 3.13 \\
\hline 2011 & 122.2 & 98.00 & 1.00 & 84.63 & 2.17 & 100.00 & 2.00 & 94.75 & 2.74 \\
\hline 2012 & 166.9 & 97.31 & 2.50 & 107.3 & 2.64 & 54.51 & 2.05 & 65.69 & 2.44 \\
\hline 2013 & 261.1 & 57.04 & 2.32 & 95.68 & 2.82 & 50.18 & 1.90 & 57.40 & 3.01 \\
\hline 2014 & 257.4 & 62.89 & 2.03 & 69.74 & 3.66 & 48.25 & 1.71 & 54.78 & 3.25 \\
\hline 2015 & 257.5 & 65.14 & 2.19 & 98.23 & 2.88 & 46.02 & 1.95 & 56.80 & 2.82 \\
\hline 2016 & 243.15 & 68.93 & 2.71 & 137.3 & 2.01 & 69.05 & 3.06 & 123.99 & 1.35 \\
\hline
\end{tabular}


Table 3: Kura River yearly data 2009-2016 along section \#2-\#2a.

\begin{tabular}{|c|c|c|c|c|c|c|c|c|c|}
\hline \multirow[b]{2}{*}{ Year } & \multirow[b]{2}{*}{ Island width, m } & \multicolumn{4}{|c|}{ Left Sleeve } & \multicolumn{4}{|c|}{ Right Sleeve } \\
\hline & & $\begin{array}{l}\text { Width of } \\
\text { left sleeve, } \\
\text { m }\end{array}$ & $\begin{array}{l}\text { Maximal } \\
\text { depth of left } \\
\text { sleeve, } \mathrm{m}\end{array}$ & $\begin{array}{l}\text { Cross sec- } \\
\text { tion of left } \\
\text { sleeve, } \mathbf{m}^{2}\end{array}$ & $\begin{array}{l}\text { River flow } \\
\text { rate in left } \\
\text { sleeve, } \\
\text { m/s }\end{array}$ & $\begin{array}{c}\text { Width } \\
\text { of right } \\
\text { sleeve, m }\end{array}$ & $\begin{array}{l}\text { Maximal } \\
\text { depth of right } \\
\text { sleeve, } \mathbf{m}\end{array}$ & $\begin{array}{l}\text { Cross sec- } \\
\text { tion of right } \\
\text { sleeve, } \mathbf{m}^{2}\end{array}$ & $\begin{array}{c}\text { River flow } \\
\text { rate in right } \\
\text { sleeve, } \mathrm{m} / \mathrm{s}\end{array}$ \\
\hline 2009 & 158.51 & 112.69 & 1.93 & 83.19 & 2.99 & 92.93 & 0.91 & 66.21 & 2.93 \\
\hline 2010 & 131.4 & 87.73 & 1.43 & 82.5 & 2.71 & 98.31 & 1.35 & 82.54 & 2.66 \\
\hline 2011 & 101.79 & 127.31 & 1.53 & 99.87 & 1.84 & 105.05 & 3.42 & 199.2 & 1.3 \\
\hline 2012 & 152.01 & 108.07 & 2.37 & 140.35 & 2.02 & 46.72 & 2.45 & 73.3 & 2.18 \\
\hline 2013 & 249.13 & 63.3 & 1.98 & 83.29 & 3.24 & 39.74 & 2.69 & 63.19 & 2.74 \\
\hline 2014 & 248.42 & 67.68 & 1.4 & 75.06 & 3.4 & 38.43 & 2.77 & 62.76 & 2.99 \\
\hline 2015 & 247.62 & 70.66 & 2 & 104.07 & 2.71 & 41.31 & 2.9 & 79.76 & 2.01 \\
\hline 2016 & 228.86 & 77.42 & 3.51 & 201.44 & 1.33 & 59.77 & 3.56 & 108.03 & 1.54 \\
\hline
\end{tabular}

Table 4: Kura River yearly data 2009-2016 along section \#3-\#3a.

\begin{tabular}{|c|c|c|c|c|c|c|c|c|c|}
\hline \multirow{2}{*}{ Year } & \multirow{2}{*}{$\begin{array}{c}\text { Island } \\
\text { Width, } \mathbf{m}\end{array}$} & $\begin{array}{c}\text { Width of } \\
\text { left sleeve, } \\
\mathbf{m}\end{array}$ & $\begin{array}{c}\text { Maximal } \\
\text { depth of left } \\
\text { sleeve, } \mathbf{m}\end{array}$ & $\begin{array}{c}\text { Cross sec- } \\
\text { tion of left } \\
\text { sleeve, } \mathbf{~ m}^{2}\end{array}$ & $\begin{array}{c}\text { River flow } \\
\text { rate in left } \\
\text { sleeve, } \mathbf{m} / \mathbf{s}\end{array}$ & $\begin{array}{c}\text { Width } \\
\text { of right } \\
\text { sleeve, } \mathbf{m}\end{array}$ & $\begin{array}{c}\text { Maximal } \\
\text { depth of } \\
\text { right sleeve, } \\
\mathbf{m}\end{array}$ & $\begin{array}{c}\text { Cross section } \\
\text { of right } \\
\text { sleeve, } \mathbf{m}^{2}\end{array}$ & $\begin{array}{c}\text { River flow } \\
\text { rate in right } \\
\text { sleeve, } \mathbf{m} / \mathbf{s}\end{array}$ \\
\hline 2009 & 188.34 & 79.61 & 2.52 & 67.29 & 3.70 & 107.25 & 0.87 & 67.68 & 2.87 \\
\hline 2010 & 166.54 & 89.69 & 1.91 & 88.35 & 2.53 & 95.19 & 1.41 & 81.0 & 2.71 \\
\hline 2011 & 143.02 & 89.78 & 1.61 & 78.15 & 2.35 & 92.68 & & 82.08 & 3.16 \\
\hline 2012 & 174.13 & 89.94 & 2.42 & 105.07 & 2.69 & 61.22 & 1.77 & 1.85 & 2.65 \\
\hline 2013 & 273.48 & 51.36 & 2.38 & 99.39 & 2.72 & 49.62 & 1.69 & 51.51 & 3.36 \\
\hline 2014 & 268.32 & 57.27 & 2.62 & 101.03 & 2.53 & 49.66 & 1.42 & 49.4 & 3.80 \\
\hline 2015 & 267.72 & 60.97 & 2.64 & 101.3 & 2.79 & 47.22 & 1.76 & 59.73 & 2.71 \\
\hline 2016 & 251.21 & 71.85 & 3.74 & 187.63 & 1.42 & 62.28 & 2.45 & 107.45 & 1.55 \\
\hline
\end{tabular}

Table 5: Kura River yearly data 2009-2016 along section \#4-\#4a.

\begin{tabular}{|c|c|c|c|c|c|c|c|c|c|}
\hline \multirow{2}{*}{ Year } & \multirow{2}{*}{$\begin{array}{c}\text { Island } \\
\text { Width, } \mathbf{m}\end{array}$} & $\begin{array}{c}\text { Width of left } \\
\text { sleeve, } \mathbf{m}\end{array}$ & $\begin{array}{c}\text { Maximal depth } \\
\text { of left sleeve, } \mathbf{m}\end{array}$ & $\begin{array}{c}\text { Left Sleeve } \\
\text { Cross sec- } \\
\text { tion of left } \\
\text { sleeve, } \mathbf{m}^{2}\end{array}$ & $\begin{array}{c}\text { River flow } \\
\text { rate in left } \\
\text { sleeve, } \mathbf{m} / \mathbf{s}\end{array}$ & $\begin{array}{c}\text { Width } \\
\text { of right } \\
\text { sleeve, } \mathbf{m}\end{array}$ & $\begin{array}{c}\text { Maximal } \\
\text { depth of right } \\
\text { sleeve, } \mathbf{m}\end{array}$ & $\begin{array}{c}\text { River } \\
\text { Cross sec- } \\
\text { tion of right } \\
\text { sleeve, } \mathbf{m}^{2}\end{array}$ \\
$\begin{array}{c}\text { flow rate } \\
\text { in right } \\
\text { sleeve, } \\
\mathbf{m} / \mathbf{s}\end{array}$ \\
\hline 2009 & 312.90 & 64.83 & 1.20 & 41.44 & 3.28 & 54.95 & 2.11 & 75.78 & 4.69 \\
\hline 2010 & 329.98 & 66.94 & 1.69 & 69.6 & 3.21 & 99.36 & 1.49 & 86.73 & 2.53 \\
\hline 2011 & 408.31 & 103.45 & 1.33 & 77.89 & 2.36 & 81.24 & 2.26 & 105.47 & 2.46 \\
\hline 2012 & 403.93 & 118.29 & 1.30 & 123.49 & 2.29 & 79.83 & 1.88 & 96.98 & 2.29 \\
\hline 2013 & 416.91 & 70.6 & 2.05 & 97.16 & 2.78 & 81.12 & 1.30 & 68.41 & 2.53 \\
\hline 2014 & 409.43 & 80.55 & 1.64 & 81.64 & 3.13 & 78.97 & 1.25 & 70.75 & 2.65 \\
\hline 2016 & 395.68 & 93.09 & 1.28 & 99.50 & 2.84 & 81.77 & 0.59 & 33.05 & 4.85 \\
\hline
\end{tabular}

Island formation:

A. The width of the island along section \#0-\#0a increased by $73.45 \mathrm{~m}$ (from $169.7 \mathrm{~m}$ in 2009 to $243.15 \mathrm{~m}$ in 2016 ).

Changes observed in the left sleeve of the Kura River are as follows:
B. The width of the sleeve decreased by $18.4 \mathrm{~m}$ (from $87.33 \mathrm{~m}$ in 2009 to $68.93 \mathrm{~m}$ in 2016).

C. Maximum depth of the river increased by $0.36 \mathrm{~m}$ (from $2.35 \mathrm{~m}$ in 2009 to $2.71 \mathrm{~m}$ to 2016 ).

Changes observed in the right sleeve of the Kura River are as follows: 
D. The width of the sleeve decreased by $44.66 \mathrm{~m}$ (from $113.71 \mathrm{~m}$ in 2009 to $69.05 \mathrm{~m}$ in 2016).

E. Maximum depth of the river increased by $2.13 \mathrm{~m}$ (from $0.93 \mathrm{~m}$ in 2009 to $3.06 \mathrm{~m}$ to 2016 ).

Island formation:

A. The width of the island along section \#2-\#2a increased by $70.35 \mathrm{~m}$ (from $158.51 \mathrm{~m}$ in 2009 to $228.86 \mathrm{~m}$ in 2016).

Changes observed in the left sleeve of the Kura River are as follows:

B. The width of the sleeve decreased by $35.27 \mathrm{~m}$ (from $112.69 \mathrm{~m}$ in 2009 to $77.42 \mathrm{~m}$ in 2016).

C. Maximum depth of the river increased by $1.58 \mathrm{~m}$ (from $1.93 \mathrm{~m}$ in 2009 to $3.51 \mathrm{~m}$ to 2016 ).

Changes observed in the right sleeve of the Kura River are as follows:

D. The width of the sleeve decreased by $33.16 \mathrm{~m}$ (from $92.93 \mathrm{~m}$ in 2009 to $59.77 \mathrm{~m}$ in 2016).

E. Maximum depth of the river increased by $2.65 \mathrm{~m}$ (from $0.91 \mathrm{~m}$ in 2009 to $3.56 \mathrm{~m}$ to 2016 ).

Island formation:

A. The width of the island along section \#3-\#3a increased by $62.87 \mathrm{~m}$ (from $188.34 \mathrm{~m}$ in 2009 to $251.21 \mathrm{~m}$ in 2016).

Changes observed in the left sleeve of the Kura River are as follows:

B. The width of the sleeve decreased by $7.76 \mathrm{~m}$ (from $79.61 \mathrm{~m}$ in 2009 to $71.85 \mathrm{~m}$ in 2016).

C. Maximum depth of the river increased by $1.22 \mathrm{~m}$ (from $2.52 \mathrm{~m}$ in 2009 to $3.74 \mathrm{~m}$ to 2016 ).

Changes observed in the right sleeve of the Kura River are as follows:

D. The width of the sleeve decreased by $44.97 \mathrm{~m}$ (from $107.25 \mathrm{~m}$ in 2009 to $62.28 \mathrm{~m}$ in 2016).

E. Maximum depth of the river increased by $1.58 \mathrm{~m}$ (from $0.87 \mathrm{~m}$ in 2009 to $2.45 \mathrm{~m}$ to 2016 ).

\section{Island formation:}

A. The width of the island along section \#4-\#4a increased by $34.40 \mathrm{~m}$ (from $312.90 \mathrm{~m}$ in 2009 to $347.30 \mathrm{~m}$ in 2016 ).

Changes observed in the left sleeve of the Kura River are as follows:

B. The width of the sleeve increased by $64.14 \mathrm{~m}$ (from $64.83 \mathrm{~m}$ in 2009 to $128.97 \mathrm{~m}$ in 2016).

C. Maximum depth of the river increased by $1.66 \mathrm{~m}$ (from $1.20 \mathrm{~m}$ in 2009 to $2.86 \mathrm{~m}$ to 2016 ).
Changes observed in the right sleeve of the Kura River are as follows:

D. The width of the sleeve increased by $42.03 \mathrm{~m}$ (from $54.95 \mathrm{~m}$ in 2009 to $96.98 \mathrm{~m}$ in 2016).

E. Maximum depth of the river decreased by $0.39 \mathrm{~m}$ (from $2.11 \mathrm{~m}$ in 2009 to $1.72 \mathrm{~m}$ to 2016 ).

Summarising the analysis of the river history, we can conclude that the river sleeves along the considered sections \#0-\#0a, \#2$\# 2 \mathrm{a}$ and \#3-\#3a decreased in width with time except for section \#4-\#4a.

\section{River banks erosion}

River banks erosion process reflects the interaction of the river stream and its channel. Together with erosion, the accumulation of alluvial material is observed on the opposite bank (in our case, on the island coast). The intensity of erosion depends on the angle of the stream towards the river bank: the greater the angle, the higher the erosion rate. In the straight river channel, the stream center is in the center of the channel and therefore the river velocity is at its maximum in the center of the channel and minimum at the river banks (in this case the section of the river is close to a parabola form) and no erosion is observed. When the river stream is angled towards the river bank, the convergence of streams occur near the bank and stream velocity increases due to its constriction.

Thus, river bank erosion occurs which often forms a steep cliff. The water table skewness stipulates the beginning of circulating stream with ground flow directed from the eroded bank. As the ground flows contain maximum amount of alluvia, the direction of the stream leads to formation of riverine shelves, which in turn leads to higher constriction of the river channel. As a result, the parabolic form of the river channel tends to a triangle formation.

\section{Discussion}

Based on the river and island histories and studies, we can outline general tendencies in the Kura River behavior, island growth and river banks erosion. The river banks at the section \#0-\#0a are reinforced with rip raps and therefore the potential of erosion at these points is not high. The river sleeves at the pipeline crossing tend to decrease in width and increase in depth, which looks to be the biggest threat to the pipeline in its current state. The cross section of each sleeve also increases (at points where the pipelines cross the river). However, the flow rate (the ratio between inertial forces and viscous forces) is higher in 2016, which is due to decreased values of wetted perimeters of the river sleeves.

Further growth of the alluvial island and subsequent narrowing of the river sleeves can possibly bring to a change in sleeve depths. However, the fact that there is no information regarding the material of the river bed, makes it difficult to predict its behavior. The material of the alluvial island is mainly gravel and coarse sand with some topsoil potentially brought by the river stream. The water in the Kura River is muddy and the stream velocity is high enough to bring necessary sand and gravel material from upstream. 
Therefore, we may expect that the island forming processes will continue in the future with further constriction of the Kura River sleeves in the pipeline section. Hence, the issue must be addressed, and preventive measures undertaken prior to the further growth that has the potential to damage the pipeline.

To protect the pipeline, which is located under the Kura River bed, it is necessary to minimize the river depths in the sleeves where the pipeline crosses as is shown on Figure $3 \& 4$. For that the river bed must be backfilled with clay and covered with protecting gravel and pebbles layers. This alone however will bring to unpredictable

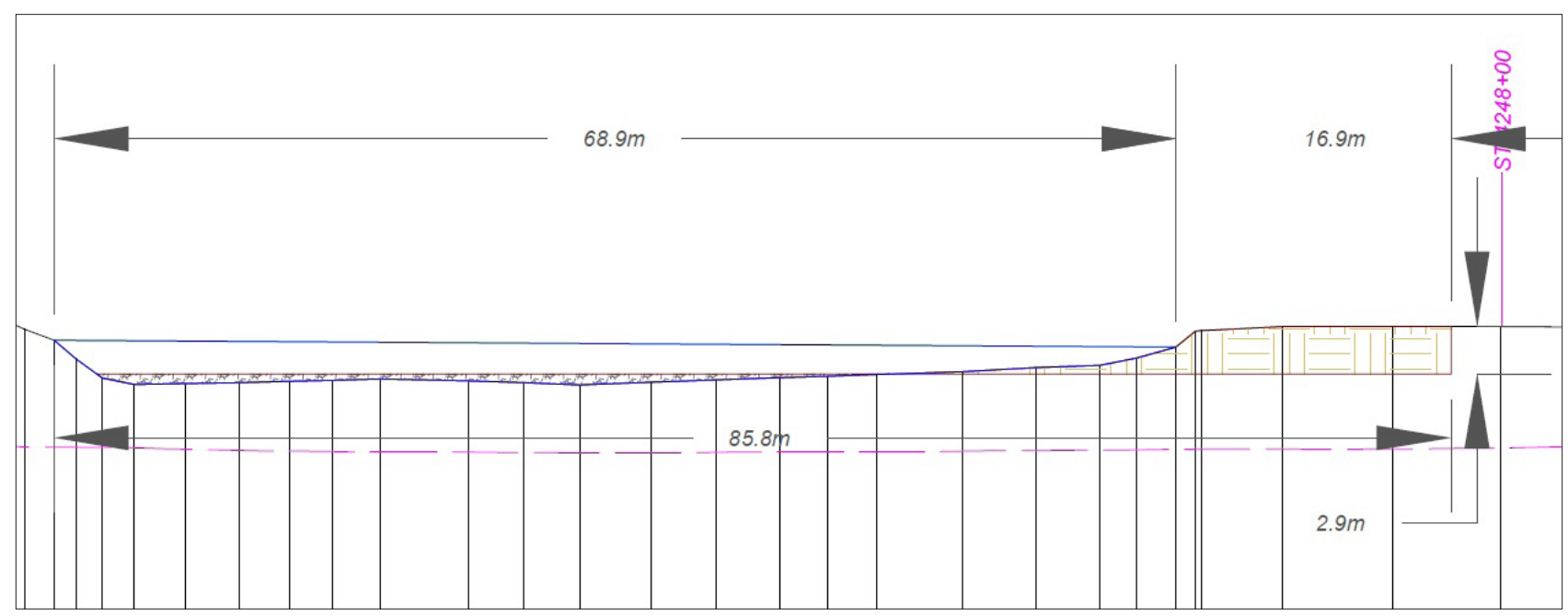

Figure 3: Section of the left sleeve with proposed actions (yellow shaded area indicates the excavation of the island shore; grey shaded area shows installation of the backfill material on the river bed).

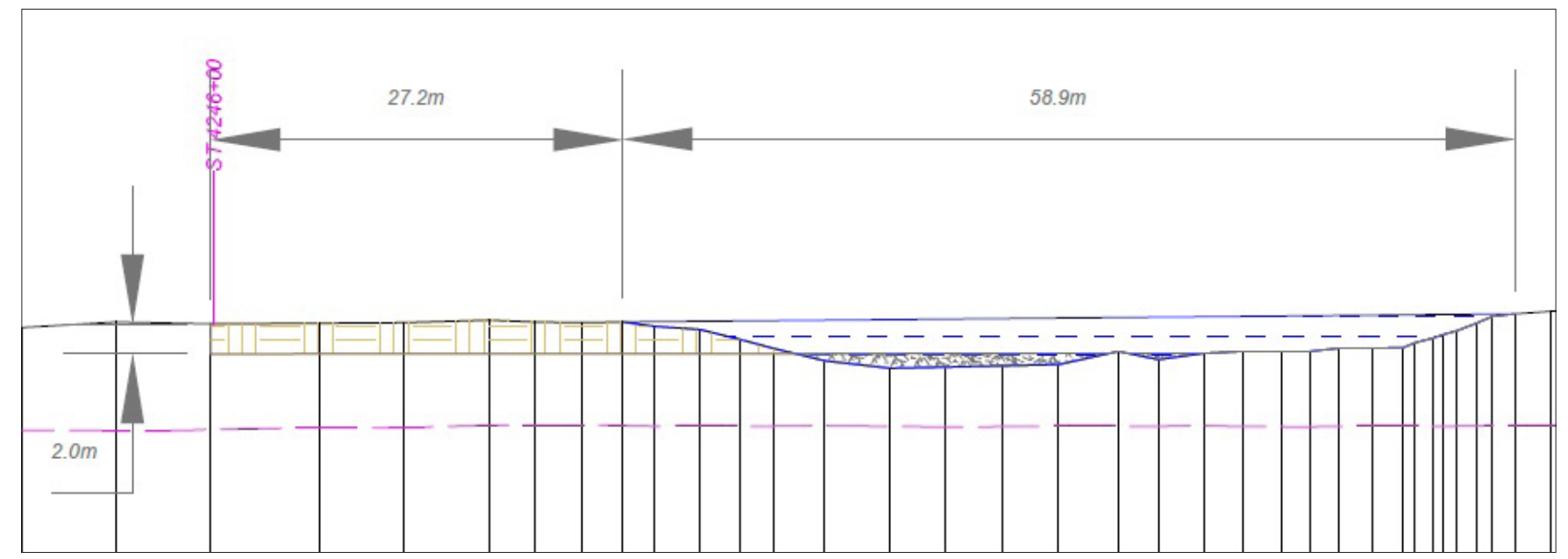

Figure 4: Section of the right sleeve with proposed actions (yellow shaded area indicates the excavation of the island shore; grey shaded area shows installation of the backfill material on the river bed).

\section{Recommendation}

The principal problem at present appears to be the right sleeve of the river. Hence, it is recommended to consider widening of this sleeve area and reinforcing its river bed. This can be implemented by:

A. Conducting a river bed investigation to obtain information regarding river bed material. results due to further increase of flow rates in the sleeves. To avoid this, i.e., to decrease flow rates and increase stability, it is necessary to increase the sleeves' width by excavation of soil at the alluvial island shores. Excavation covers the areas where the river sleeve width is critically low and increased water flow may cause erosion of the beds. Another preventing issue is the coastal line reinforcement after increasing the widths of the sleeves, i.e. the banks of the island must also be reinforced using rip-rap. It also is important to provide a uniform section of the river in the areas where the pipeline is located, as shown in Figure 5. This will minimize the disturbance of the riverbed by unstable flows and locally increased turbulences. 
further washing out (amount of backfill material is $12730 \mathrm{~m}^{3}$ for the left sleeve and $10436 \mathrm{~m}^{3}$ for the right sleeve).
D. When conducting these works, attention shall be paid to arranging a profile such that the water stream influence on erosion is minimal (construe an optimal angle).

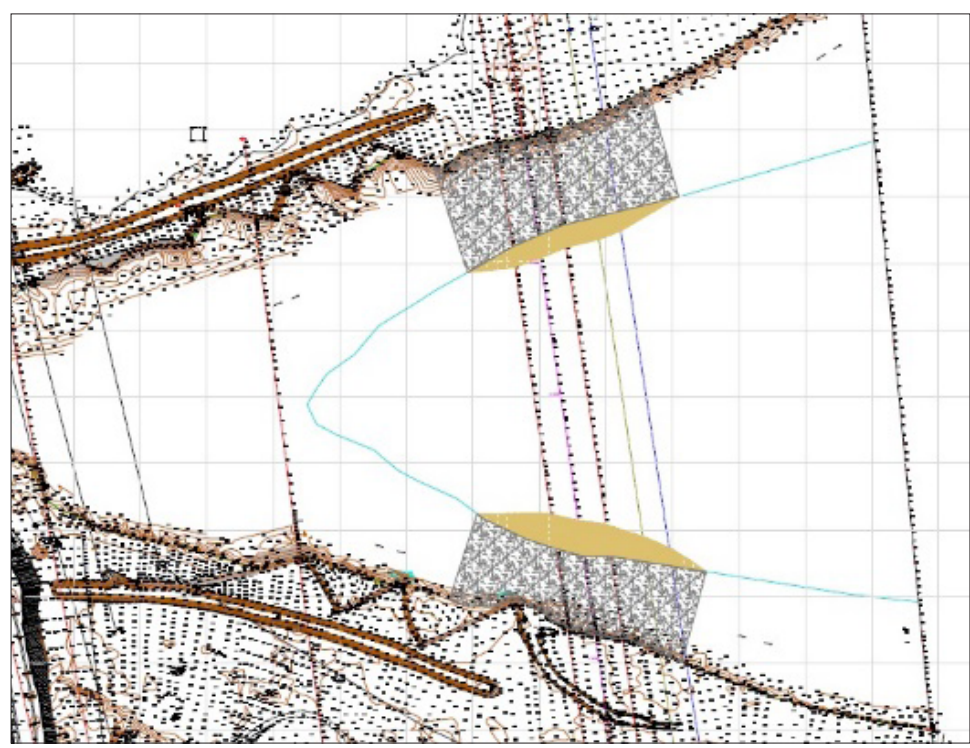

Figure 5: Proposed actions for Kura River crossing remediation (yellow shaded area indicates the excavation of the island shores; grey shaded area shows installation of the backfill material on the river bed)..

\section{Conclusion}

Based on above measurements it can be concluded below items as outcomes of the research work:

A. The river banks at the areas of the pipeline crossing remain intact due to reinforcement. This however resulted in the river bed deepening (due to alluvium).

B. The water depth on the right sleeve of the river has significantly increased and may constitute a risk to the pipeline integrity.

c. The narrowing of the sleeves is another threat to the pipeline as it may further tend to deepen the water levels. As the banks are reinforced (riprap), and the island size increases due to alluvium, the river bed is being washed out.

D. The material of the river bed at the point of maximum water depth is unknown (e.g. it's potential for being washed out and its permeability).

E. The cross section of the river sleeve in the pipeline crossing areas increases with the flow velocity decreasing, however this results in river bed deepening, which may threaten pipeline integrity.
A more precise data related to the subject river area were requested from the Ministry of Ecology, including water velocities and maximum overflows. Those will be required to develop a detailed design and calculations.

\section{References}

1. Hydrological information registered at the Kura-Giragkesemen hydrological station and provided by Ministry of Ecology and Natural Resources of Azerbaijan Republic (National Hydrometeorology Department).

2. Sefer K, Bahar N, Rustam BR (2014) Advances of space technology in geotechnical studies, global journal of researches in engineering. J General Engineering 14(6).

3. Amil TA, Rustam BR (2015) Remote sensing and geographic information system/geodatabase in river flood mapping. Journal of Surveying and Mapping Engineering 3(1): 1-11.

4. Xia X, Liang Q, Ming X, Hou J (2017) An efficient and stable hydrodynamic model with novel source term discretization schemes for overland flow and flood simulations. Water Resour 53: 3730-3759.

5. Vitaly B (2014) Regression-based daugava river flood forecasting and monitoring, information technology and management science. Versita 16(1): 137-142. 